УДК 633.15:581.143.6

Т. М. Сатарова, Н. Ф. Павлюкова, Т. І. Юсипіва

Дніпропетровський наиіональний університет ім. Олеся Гончара

\title{
ДОСЛІДЖЕННЯ АБСЦИЗОВОЇ КИСЛОТИ \\ ЯК ІНГІБІТОРА ПРОРОСТАННЯ НАСІННЯ КУКУРУДЗИ ДЛЯ ВИКОРИСТАННЯ В БІОТЕХНОЛОГІЧНИХ ПРОГРАМАХ
}

Досліджено особливості росту та розвитку проростків кукурудзи під впливом абсцизової кислоти в діапазонах концентрацій 0,1-1,0, 10-100, 400 та 1000 мг/л. Показано, що інгібуюча дія навіть надвисоких концентрацій АБК зникає після припинення дії цього фактора. Цей підхід може бути застосований у біотехнологічних програмах тривалого зберігання селекційного матеріалу кукурудзи.

T. M. Satarova, N. F. Pavlyukova, T. I. Yusypiva

Oles' Gonchar Dnipropetrovsk National University

\section{STUDY OF ABSCISIC ACID AS AN INHIBITOR OF THE MAIZE SEEDLINGS EMERGENCE AND ITS USE IN BIOTECHNOLOGY}

The peculiarities of the growth and development of maize seedlings under the influence of abscisic acid (ABA) in the range of concentrations 0.1-1.0, 10-100, 400 and $1000 \mathrm{mg} / \mathrm{l}$ were studied. It was shown that inhibitory effect even under ultrahigh concentrations of ABA disappeared after the breaking its influence off. The given approach can be applied to biotechnological programs on long-term preservation of breeding material of maize.

\section{Вступ}

У біотехнології та селекції рослин рослин часто виникає необхідність переведення недозрілого насіння або ізольованих зародків у культурі in vitro у стан спокою, зберігання та пророщування їх після виходу зі стану спокою. Зокрема, актуальний такий підхід для кукурудзи. Зберігання насіння та зародків, ізольованих у незрілому стані, актуальне у таких селекційних програмах цієї культури, як одержання декількох генерацій на рік при переведенні ліній на цитоплазматичну чоловічу стерильність і насичувальних схрещуваннях, селекції пізньостиглих форм та інших.

Фітогормоном, який забезпечує та регулює стан спокою у рослин, є абсцизова кислота (АБК). Вона відноситься до групи біологічно активних речовин, за допомогою яких можливе управління спокоєм і старінням рослин. АБК характеризується високою біологічною активністю, швидким пересуванням по рослині та іншими якостями фітогормонів. У клітині АБК інгібує процеси реплікації, транскрипції та трансляції шляхом зниження активності ДНК- та РНК-полімераз, підвищення активності РНКази, посилення біосинтезу інших ферментів і регуляторних білків, порушення утворення полісом, зниження активності аміноацил-т-РНК-синтетаз [1].

Абсцизова кислота як фітогормон виступає регулятором експресії генів у відповідь на дію стимуляторів росту та абіотичних стресів. Вона може індукувати експресію антиоксидантних генів та посилювати можливості антиоксидантних систем, включаю-

(C) Т. М. Сатарова, Н. Ф. Павлюкова, Т. І. Юсипіва, 2008 
чи ензиматичні та неензиматичні їх компоненти $[6 ; 8 ; 12 ; 13]$. На пізніх стадіях ембріогенезу поряд із підвищенням вмісту АБК у насінні з'являються специфічні РНК і специфічні білки. Це так звані білки пізнього ембріогенезу, які беруть участь у забезпеченні стійкості зародка до зневоднення. Обробка АБК підвищує вміст цих білків. На пізніх етапах ембріогенезу АБК відіграє суттєву роль у регуляції транспорту асимілянтів із насіннєвої оболонки до зародка [5].

За результатами недавніх досліджень установлено, що медіаторами генної експреciї, залежної від абсцизової кислоти, виступають члени родини факторів транскрипції bZIP, такі як ABRE cis-елемент, EmBP-2 та ZmBZ-1. Останні два фактори диференційовано експресуються у період ембріогенезу. ЕmBP-2 є конститутивним, a ZmBZ-1 індуцибельним, залежним від абсцизової кислоти фактором, причому останній акумулюється у період пізнього ембріогенезу. Фактори EmBP-2 та ZmBZ-1 - ядерні протеїни. Зокрема, вони активують транскрипцію гена $r a b 28$ кукурудзи, який індукується абсцизовою кислотою. EmBP-2 та ZmBZ-1 фосфорилюються протеїнкіназою СК2, причому ця модифікація змінює їх здатність зв'язуватися з ДНК. EmBP-2 та ZmBZ-1 залучені до експресії декількох індуцибельних генів, залежних від абсцизової кислоти, подібних $r a b 28$, а їх активність модулюється АБК та фосфорилюванням [11]. Методами генної інженерії доведено, що за позитивну регуляцію експресії з боку АБК для гена кукурудзи Glb1 відповідає Em1а-послідовність у 5'-регуляторній ділянці цього гена [7].

Абсцизова кислота задіяна також у регуляції програмованої смерті клітин ендосперму. Відомо, що ендосперм злаків у період розвитку піддається програмованій клітинній смерті, яка частково контролюється етиленом. T. Young та D. Gallie [14] показали, що баланс між АБК та етиленом визначає можливий початок і прогресування програмованої клітинної смерті у період розвитку ендосперму кукурудзи. Незважаючи на значні успіхи у з'ясуванні молекулярного механізму різних аспектів дії АБК, ії використання у рослинництві, зокрема у різноманітних біотехнологічних і селекційних програмах тих або інших культур обмежене нестачею відомостей про характер їі впливу на різних стадіях формування насіння, концентрації, експозиції та способу дії.

За даними F. Fong зі співавторами [10], спокій насіння кукурудзи індукується приблизно з 9-ї по 11-у добу після запилення. 3 14-ї доби спокій підтримується високим рівнем АБК. Генотипи кукурудзи суттєво розрізняються за вмістом АБК у нестиглих зернівках [9]. Вивчення впливу абсцизової кислоти на затримку проростання незрілих зародків кукурудзи в культурі in vitro було розпочате декілька років тому. Дослідники мали на меті забезпечити збереження цінного селекційного матеріалу в умовах in vitro, який за різних обставин на момент збирання врожаю виявляється незрілим. Показано [4], що незрілі зародки різних генотипів кукурудзи здатні проростати після тримісячного зберігання на холоді в умовах in vitro. Але необхідним виявилося подальше доопрацювання технології одержання міцніших, добре розвинених, зелених проростків після тривалого зберігання на холоді.

У роботі [4] викладено думку, що безкольоровість значної кількості проростків, одержаних після дії холоду протягом 3 місяців, та їх ослабленість пов'язані з неглибоким станом спокою при температурі $+5 \ldots+7^{\circ} \mathrm{C}$. Тому подальші дослідження можливості забезпечення глибокого стану спокою у незрілих ізольованих зародків кукурудзи за допомогою таких агентів, як абсцизова кислота, $\epsilon$ актуальними. Дослідження впливу широкого спектра концентрацій АБК на спокій та проростання незрілих зародків кукурудзи за умов in vitro зіштовхуються з великими труднощами та можуть проводитися лише у дуже короткий період року. Із цієї причини вирішено дослідити залежність росту та розвитку проростків від концентрації АБК у модельних експериментах із сухим стиглим насін- 
ням кукурудзи для подальшого застосування отриманих результатів у дослідженнях незрілих зародків за умов in vitro. Мета цієї роботи - оцінити вплив абсцизової кислоти у різних діапазонах концентрацій на проростання зрілого насіння кукурудзи.

\section{Матеріал і методи досліджень}

У роботі використане зріле насіння гібриду кукурудзи Соколов 407, люб'язно надане Інститутом зернового господарства УААН. Вплив абсцизової кислоти на проростання насіння досліджували у діапазонах концентрацій $0,1-1,0$ мг/л $\left(3,4 \cdot 10^{-7}-3,4 \cdot 10^{-6} \mathrm{M}\right)$, 10-100 мг/л $\left(3,4 \cdot 10^{-5}-3,4 \cdot 10^{-4} \mathrm{M}\right), 400$ і 1000 мг/л $\left(1,4 \cdot 10^{-5}\right.$ і $\left.3,4 \cdot 10^{-3} \mathrm{M}\right)$. Контрольним варіантом було пророщування на дистильованій воді без додавання абсцизової кислоти. Пророщування вели у чашках Петрі на фільтрувальному папері, змоченому дистильованою водою або розчином АБК відповідної концентрації, при температурі $+26 \ldots+27^{\circ} \mathrm{C}$ у темряві протягом 6 діб. Таким чином, дія АБК на зернівки та проростки мала місце протягом усього часу пророщування. Після 6 діб пророщування зернівок отримані проростки аналізували за наступними параметрами: відсоток проростання (пророслими вважали насінини, у яких довжина пагона була більшою за довжину зернівки), довжина пагона, довжина кореневої системи. Статистичну обробку результатів проводили за Г. Ф. Лакіним [3]. На кожний варіант досліду аналізували по 30 зернівок.

\section{Результати та їх обговорення}

Відсоток проростання насіння кукурудзи після обробки невеликими концентраціями АБК (табл. 1) знижувався починаючи з концентрацій 0,4 мг/л (98 \%) до 1 мг/л (93\%). Обробка АБК зменшувала довжину пагонів (починаючи 3 концентрації 0,3 мг/л) і кореневої системи порівняно 3 контролем (починаючи 3 концентрації 0,2 мг/л). Отримані дані щодо морфобіологічних показників при поступовому рівномірному збільшенні концентрації АБК дозволили охарактеризувати закономірності розвитку проростків за дії цього фактора. Між діючою концентрацією АБК в діапазоні 0,11,0 мг/л, довжиною кореневої системи та довжиною пагона при пророщуванні зрілих зернівок існує достовірна негативна кореляція. Регресійний аналіз показує, що залежність довжини кореневої системи від концентрації АБК у діапазоні 0,1-1,0 мг/л відповідає рівнянню $y=14,3-6,1 x$, а залежність довжини пагона від того ж фактора - рівнянню $y=10,5-5,4 x$.

Табличя 1

Вплив обробки зернівок кукурудзи абсцизовою кислотою (у концентраціях 0,1-1,0 мг/л) на морфологічні показники проростків

\begin{tabular}{|c|c|c|}
\hline $\begin{array}{c}\text { Концентрація розчину АБК, } \\
\text { мг/л }\end{array}$ & $\begin{array}{c}\text { Довжина кореневої системи } \\
\left(x \pm m t_{0,05}\right), \mathrm{cm}\end{array}$ & $\begin{array}{c}\text { Довжина пагона } \\
\left(x \pm m t_{0,05}\right), \mathrm{cm}\end{array}$ \\
\hline 0,0 & $16,0 \pm 1,4$ & $10,8 \pm 0,9$ \\
\hline 0,1 & $15,3 \pm 1,2$ & $9,2 \pm 0,6$ \\
\hline 0,2 & $11,7 \pm 0,9$ & $7,2 \pm 0,4$ \\
\hline 0,3 & $9,1 \pm 0,6$ & $8,8 \pm 0,5$ \\
\hline 0,4 & $11,9 \pm 0,8$ & $6,9 \pm 0,7$ \\
\hline 0,5 & $10,3 \pm 0,8$ & $6,3 \pm 0,8$ \\
\hline 0,6 & $9,3 \pm 1,2$ & $6,9 \pm 0,5$ \\
\hline 0,7 & $12,0 \pm 0,6$ & $5,0 \pm 0,8$ \\
\hline 0,8 & $8,3 \pm 1,3$ & $6,7 \pm 0,5$ \\
\hline 0,9 & $11,4 \pm 0,6$ & $6,3 \pm 0,4$ \\
\hline 1,0 & $7,7 \pm 0,6$ & $r_{13}=-0,86^{*}$ \\
\hline
\end{tabular}

Примітка: * - коефіцієнти кореляції достовірні на рівні значущості 0,05. 
Проростання насіння кукурудзи за дії високих концентрацій АБК (табл. 2) суттєво знижувалось зі зростанням вмісту АБК у розчині. Такі концентрації АБК інгібували розвиток кореневої системи та пагона проростка, причому залежність була достовірно негативною. Регресійний аналіз показує, що залежність довжини кореневої системи від концентрації АБК у діапазоні 10-100 мг/л відповідає рівнянню $y=4,66-0,03 x+\frac{7,00}{x}$, а залежність довжини пагона - рівнянню $y=3,7-0,04 x+\frac{4 \cdot 10^{-5}}{x}$.

Вплив обробки зернівок кукурудзи абсцизовою кислотою (у концентрації 10-100 мг/л) на морфобіологічні показники проростків

\begin{tabular}{|c|c|c|}
\hline $\begin{array}{c}\text { Концентрація розчину АБК, } \\
\text { мг/л }\end{array}$ & $\begin{array}{c}\text { Довжина кореневої системи } \\
\left(x \pm m t_{0,05}\right), \text { см }\end{array}$ & $\begin{array}{c}\text { Довжина пагона } \\
\left(x \pm m t_{0,05}\right), \text { см }\end{array}$ \\
\hline 0 & $11,2 \pm 1,3$ & $7,9 \pm 0,4$ \\
\hline 10 & $4,7 \pm 0,6$ & $4,5 \pm 0,3$ \\
\hline 20 & $4,3 \pm 0,7$ & $2,5 \pm 0,5$ \\
\hline 30 & $3,5 \pm 0,5$ & $2,3 \pm 0,3$ \\
\hline 40 & $4,0 \pm 0,5$ & $1,9 \pm 0,3$ \\
\hline 50 & $3,6 \pm 0,4$ & $1,6 \pm 0,3$ \\
\hline 60 & $3,2 \pm 0,4$ & $1,0 \pm 0,2$ \\
\hline 70 & $2,3 \pm 0,3$ & $0,7 \pm 0,2$ \\
\hline 80 & $2,1 \pm 0,4$ & $0,6 \pm 0,2$ \\
\hline 90 & $1,8 \pm 0,4$ & $0,5 \pm 0,1$ \\
\hline 100 & $1,4 \pm 0,2$ & $0,3 \pm 0,1$ \\
\hline Коефіцієнт кореляціі & $r_{12}=-0,80^{*}$ & $r_{13}=-0,85^{*}$ \\
\hline
\end{tabular}

Примітка: * - коефіцієнти кореляції достовірні на рівні значущості 0,05.

У наступному експерименті досліджували вплив АБК у надвисоких концентраціях (400 та 1000 мг/л) на проростання. Цей експеримент проводили у такій модифікації. Насіння протягом 6 діб пророщували на фільтрувальному папері, змоченому дистильованою водою (контроль), розчином 400 мг/л АБК (експериментальний варіант 1) та розчином 1000 мг/л АБК (експериментальний варіант 2). Через 6 діб пророщування спостерігали проростання на рівні $100 \%$ насіння контрольного варіанта та майже відсутність проростання в експериментальних варіантах. Після 6 діб насіння, що пророщувалося під дією 400 і 1000 мг/л АБК і не проросло, промивали дистильованою водою, вміщували на фільтрувальний папір, змочений дистильованою водою та пророщували ще 6 діб. Ростові процеси у насінні за надвисоких (400 і 1000 мг/л) концентрацій АБК майже повністю пригнічувалися, але після зняття дії АБК через 6 діб та подальшого пророщування на дистильованій воді у певної кількості насіння відновлювалися ростові процеси (табл. 3). Це дозволяє отримувати зелені життєздатні проростки кукурудзи з насіння, яке деякий час перебувало у спокої, контрольованому екзогенною АБК.

Отримані дані щодо впливу різних концентрацій АБК добре узгоджуються з результатами досліджень на насінні дводольних, наведених у монографії [2]. Ї̈і автори зазначають, що при набуханні насіння, за наближенням до критичного для проростання рівня обводненості, вміст АБК падає до такої концентрації, що вже не інгібує проростання. В експериментах з екзогенною АБК у дводольних таке падіння концентрацій відповідало зниженню від $10^{-4}-10^{-5} \mathrm{M}$ (інгібування росту) до $10^{-6} \mathrm{M}$ (відсутність впливу на ріст), тобто зменшенню концентрації в 10-100 разів. Критичною для проростання та наступного росту проростків була концентрація між $10^{-5}$ i $10^{-6} \mathrm{M}[2]$. 
Проростання зернівок кукурудзи за дії 400 і 1000 мг/л АБК та після зняття дії АБК

\begin{tabular}{|c|c|c|c|c|}
\hline $\begin{array}{c}\text { Умови } \\
\text { експерименту }\end{array}$ & $\begin{array}{c}\text { Концентрація розчину АБК, } \\
\text { мг/л }\end{array}$ & $\begin{array}{c}\text { Довжина кореневої } \\
\text { системи }\left(x \pm m t_{0,05}\right), \mathrm{cm}\end{array}$ & $\begin{array}{c}\text { Довжина пагона } \\
\left(x \pm m t_{0,05}\right), \mathrm{cm}\end{array}$ & $\begin{array}{c}\text { Схожість, } \\
\%\end{array}$ \\
\hline \multirow{2}{*}{ За дії } & 0 & $12,2 \pm 1,5^{\mathrm{a}}$ & $8,9 \pm 0,5^{\mathrm{a}}$ & 100 \\
\cline { 2 - 5 } АБК & 400 & $0,1 \pm 0,0$ & $0,1 \pm 0,3$ & 0 \\
\cline { 2 - 5 } & 1000 & $0,1 \pm 0,0$ & $0,1 \pm 0,3$ & 0 \\
\hline Після & 0 & - & - & - \\
\cline { 2 - 5 } зняття & 400 & $5,3 \pm 0,8$ & $3,5 \pm 0,6$ & 41 \\
дії АБК & 1000 & $4,3 \pm 0,7$ & $2,6 \pm 0,5$ & 15 \\
\hline
\end{tabular}

Отримані нами дані не тільки показали, що у кукурудзи відповідні процеси відбуваються у тих самих діапазонах концентрацій, а і те, що дія надвисоких концентрацій не $є$ незворотною: після знаття дії АБК проростання насіння відновлюється.

\section{Висновки}

Дія різних концентрації абсцизової кислоти під час проростання призводить до зниження інтенсивності ростових процесів у кукурудзи. Характер впливу АБК на швидкість пригнічення росту кореневої системи та пагона перш за все залежить від діапазону концентрацій. Для невеликих концентрацій (0,1-1,0 мг/л) залежність має лінійний характер i описується рівняннями для довжини кореневої системи та пагона $y=14,3-6,1 x$ i $y=10,5-5,4 x$. Для діапазону середніх концентрацій (10-100 мг/л) інгібуючий вплив АБК проявлявся згідно 3 рівняннями відповідно для двох ознак $y=4,7-0,03 x+\frac{7,0}{x}$ i $y=3,7-0,04 x+\frac{4 \cdot 10^{-5}}{x}$. Починаючи 3 концентрацій 100 мг/л і до 1000 мг/л ріст проростків майже повністю інгібувався за постійної дії АБК на проростаючу зернівку, але після зняття дії навіть надвисоких концентрацій (400 і 1000 мг/л) ріст пагона та кореневої системи відновлювався. Останнє дозволяє рекомендувати застосування саме надвисоких концентрацій АБК у біотехнологічних дослідженнях, коли необхідно зберегти зародок недозрілої або змоченої зернини тривалий час у стані спокою, а потім домогтися проростання зародка 3 отриманням проростка.

\section{Бібліографічні посилання}

1. Калинин Ф. Л. Биологически активные вещества в растениеводстве. - К.: Наукова думка, 1984. $-388 \mathrm{c}$.

2. Природный ингибитор роста - абсцизовая кислота / В. И. Кефели, Э. М. Коф, П. В. Власов, Е. Н. Кислин. - М.: Наука, 1989. - 184 с.

3. Лакин Г. Ф. Биометрия. - М.: Высшая школа, 1990. -352 с.

4. Сатарова Т. Н. Реакция незрелых зародышей кукурузы в культуре in vitro на длительное воздействие холода / Т. Н. Сатарова, Д. Е. Струнин, П. Н. Галущак // Вісник Дніпропетровського університету. Біологія. Екологія. - 2007. - Вип. 15, т. 1. - С. 150-155.

5. Якушкина Н. И. Физиология растений / Н. И. Якушкина, Е. Ю. Бахтенко. - М.: Владос, 2005. $-463 \mathrm{c}$.

6. Abscisic acid-induced apoplastic $\mathrm{H}_{2} \mathrm{O}_{2}$ accumulation up-regulates the activities of chloroplastic and cytosolic antioxidant enzymes in maize leaves / X. Hu, M. Jiang, J. Zhang, J. Lu // Planta. 2005. - Vol. 223. - P. 57-68.

7. Abscisic acid-regulated Glb1 transient expression in cultured maize $P 3377$ cells / S. Liu, A. Kriz, D. Duncan, J. Widholm // Plant Cell Rep. - 1998. - Vol. 17, N 8. - P. 650-655. 
8. Calcium-calmodulin is required for abscisic acid-induced antioxidant defense and functions both upstream and downstream of $\mathrm{H}_{2} \mathrm{O}_{2}$ production in leaves of maize (Zea mays) plants / X. Hu, M. Jiang, J. Zhang et al. // New Phytologist. - 2007. - Vol. 173. - P. 27-38.

9. Carnes M. Endogenous hormone levels of immature corn kernels of A188, Missouri-17 and DEKALB XL-12 / M. Carnes, M. Wright // Plant Sci. - 1986. - Vol. 57. - P. 195-203.

10. Fong F. Early events in maize seed development / F. Fong, J. Smith, D. Koehler // Plant Physiol. 1983. - Vol. 73. - N 4. - P. 899-901.

11. Isolation and functional characterization of two new $b Z I P$ maize regulators of the $A B A$ responsive gene rab28 / C. Nieva, P. Busk, E. Dominguez-Puigjaner et al. // Plant Mol. Biol. - 2005. Vol. 58, N 6. - P. 899-914.

12. Mitogen-activated protein kinase is involved in abscisic acid-induced antioxidant defense and acts downstream of reactive oxygen species production in leaves of maize plants / A. Zhang, M. Jiang, J. Zhang et al. // Plant Physiology. - 2006. - Vol. 141. - P. 475-487.

13. Molecular cloning of a cytosolic ascorbate peroxidase $c D N A$ from cell cultures of sweetpotato and its expression in response to stress / S. Park, S. Ryu, I. Jang et al. // Molecular Genetics and Genomics. - 2004. - Vol. 271. - P. 339-346.

14. Young T. Regulation of programmed cell death in maize endosperm by abscisic acid / T. Young, D. Gallie // Plant Mol. Biol. - 2000. - Vol. 42, N 2. - P. 397-414.

Надійшла до редколегії 12.02.2008 